University of Cincinnati College of Law

University of Cincinnati College of Law Scholarship and

Publications

$11-2002$

\title{
Getting a Head Start: More Intake Questions and Tips for \\ Mediators
}

Marjorie Corman Aaron

University of Cincinnati College of Law, aaronmc@uc.edu

Follow this and additional works at: https://scholarship.law.uc.edu/fac_pubs

Part of the Dispute Resolution and Arbitration Commons

\section{Recommended Citation}

Marjorie Corman Aaron, Getting a Head Start: More Intake Questions and Tips for Mediators, 20

Alternatives High Cost Litig. 184, 204-205 (2002)

This Article is brought to you for free and open access by the College of Law Faculty Scholarship at University of Cincinnati College of Law Scholarship and Publications. It has been accepted for inclusion in Faculty Articles and Other Publications by an authorized administrator of University of Cincinnati College of Law Scholarship and Publications. For more information, please contact ronald.jones@uc.edu. 


\section{Getting a Head Start: More Intake Questions and Tips for Mediators}

\section{BY MARJORIE AARON}

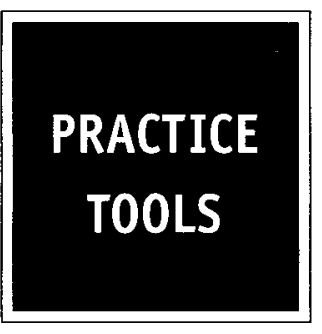

Last month, author Marjorie Aaron wrote that a party's initial inquiry to a mediator about potentially participating in a case provides many opportunities for the neutral to initiate the steps necessary for a successful resolution. The article focused on a list of intake questions for the mediator to direct to the parties. The questions included:

- Have you and your client been involved in mediation before? How did it work?

- What is the status of this dispute/case?

- How did the case get to mediation?

- Are you still in the process of selecting a mediator, or have you agreed?

The list of questions continues below.

$$
\text { -. }
$$

What is the nub of the dispute here? Is it the applicable law, or is it different views of the facts (or both)?

Even where you have explained that you don't want to raise neutrality concerns of opposing counsel by learning case details in the initial call, it is helpful to know whether the dispute is a battle over facts, or law, or both. Or something entirely different.

If you and opposing counsel were negotiating, without any involvement by the clients, do you think you could settle it, without need for mediation?

It's so much more elegant than just asking if there's a client problem, and may prompt a richer response. This question asks the attorney to make an educated guess about how much of opposing counsel posture is real-as well as his or her own position-and how much is negotiation puffery or clients' demands. Particularly where the lawyers have worked through significant discovery or motions on the case, they will have an intuitive sense of their counterpart's approach, whether he or she acknowledged a weakness uncovered in depositions, and the nature of his or her interaction with the client.

The author is a law professor at the University of Cincinnati and a mediator in private practice.
Can you describe what the dispute is about-just a bare bones description - that both parties would agree upon?

Where a "little bit" of case information before a conference call won't jeopardize perceived neutrality (particularly if you have worked with opposing counsel before), you might opt to ask for a limited description. If counsel begins explaining the client's position and view of the case too strongly, you can interject, and ask him or her just to outline a basic chronology and the issues, describing them in a way that opposing counsel would agree with the attorney.

Where you are comfortable learning more about the contacting attorney's side of the case in this initial call, you might then ask: What's your client's perspective on the dispute? Then follow up by asking: What is the other side's perspective or position?

If the mediator learns that each attorney could recite the other's legal, factual and moral positions from memory, that no one has raised a "theory of the case" or "dramatic narrative" that the other couldn't sing in rhymes, the mediator may recommend that little or no time be spent reviewing these issues in a joint session.

All too often, while the attorney is adept at articulating his client's perspective, he or she is a bit baffled or incomplete when asked how the other side views it, and why. Later, in a separate conversation with opposing counsel, when the mediator learns the other view, and the differing information or theory on which it is based, the mediator may recommend an exchange, either prior to or before the mediation session.

Please tell me a little bit about the personalities of the people involved and their relationships.

Do counsel get along? For example, has discovery been difficult? Is there anything I need to know about your client: Is he or she experienced, angry, or emotional about the case? What should I know about the clients on the other side? What are the dynamics between the parties? Is there any past history between them that might be important to know?

This is extremely important information for a mediator to have, and it is best obtained in separate conversations. The mediator will

(continued on page 204)
EDITORIAL BOARD

CHAIRMAN

THOMAS J. STIPANOWICH

CPR Institute for Dispuse Resolution

\begin{tabular}{|c|c|}
\hline $\begin{array}{l}\text { W. REECE BADER } \\
\text { Orrick, Herrington } \\
\text { \& Suscliffe }\end{array}$ & $\begin{array}{l}\text { CARRIE MENKEL-MEAD } \\
\text { Georgetonen University } \\
\text { Law Center }\end{array}$ \\
\hline $\begin{array}{l}\text { ROBERT T. BERENDT } \\
\text { Thompson Coburn }\end{array}$ & $\begin{array}{l}\text { ROBERT H. MNOOKIN } \\
\text { Harvard Law School }\end{array}$ \\
\hline $\begin{array}{l}\text { JOHN J. BOUMA } \\
\text { Snell \& Wilmer }\end{array}$ & PAUL J. MODE JR. \\
\hline $\begin{array}{l}\text { JAMIE BRODER } \\
\text { Paul }\end{array}$ & \\
\hline $\begin{array}{l}\text { Paul, Hastings, Jai } \\
\text { \& Walker }\end{array}$ & $\begin{array}{l}\text { JAMES M. RINGER } \\
\text { Rogers } \& \text { Wells }\end{array}$ \\
\hline $\begin{array}{l}\text { PAUL D. CARRINGTON } \\
\text { Duke University } \\
\text { School of Law }\end{array}$ & $\begin{array}{l}\text { A. JAMES ROBERTSOI } \\
\text { Superior Court of }\end{array}$ \\
\hline $\begin{array}{l}\text { A. STEPHENS CLAY } \\
\text { Kilpatrick \& Cody }\end{array}$ & Californ \\
\hline $\begin{array}{l}\text { Cathy A. Costantino } \\
\text { Federal Deposit } \\
\text { Insurance Corp. }\end{array}$ & $\begin{array}{l}\text { Obio State University } \\
\text { Colloge of Law }\end{array}$ \\
\hline $\begin{array}{l}\text { ROBERT A. CREO } \\
\text { Law Offices of Robert A. Creo }\end{array}$ & $\begin{array}{l}\text { DAVID L. SANDDORG } \\
\text { City University of } \\
\text { Hong Kong }\end{array}$ \\
\hline $\begin{array}{l}\text { RICHARd W. DUESENEERG } \\
\text { Monsanto } \mathrm{Ca}_{\text {. (Ret.) }}\end{array}$ & $\begin{array}{l}\text { FRAMK E.A. SAMDER } \\
\text { Harvard Lew School }\end{array}$ \\
\hline $\begin{array}{l}\text { LAURA EfFEL } \\
\text { Flippin, Densmore, } \\
\text { Morse ó Jessee }\end{array}$ & $\begin{array}{l}\text { IREME C. WARSHAUER } \\
\text { Fried } \& \text { Epstein }\end{array}$ \\
\hline $\begin{array}{l}\text { LAWRENCE J. FOX } \\
\text { Drinker, Biddle o Reash }\end{array}$ & $\begin{array}{l}\text { MELYYN I. WEISS } \\
\text { Milberg Weiss } \\
\text { Bershed }\end{array}$ \\
\hline $\begin{array}{l}\text { MARC GALANTER } \\
\text { University of Wisconsin } \\
\text { Law School }\end{array}$ & GERALD R. WILLIAMS \\
\hline $\begin{array}{l}\text { WHITMORE GRAY } \\
\text { Fordham University School } \\
\text { of Law/University of } \\
\text { Michigan Law School }\end{array}$ & $\begin{array}{l}\text { University } \\
\text { ED E. WILLIAMS III } \\
\text { United Glas Corp. }\end{array}$ \\
\hline School & $\begin{array}{l}\text { THOHAS J. WrLLIE } \\
\text { Adams \& Reese }\end{array}$ \\
\hline
\end{tabular}

Alternatives

TO THE HIGH COSTS OF LITIGATION

Publisher

Thomas J. Stipanowich

(tstipanowich@cpradr.org)

Editor

Russ Bleemer

(rbleemer@cpradr.org)

Alternatives to the High Costs of Litigation (ISSN 0736-3613) is published monthly by the CPR Institute for Dispute Resolution.

Subscription Address Changes to:

Alternatives

CPR Institute for Dispute Resolution

366 Madison Avenue, New York, NY 10017-3122

Tel: (212) 949-6490 Fax: (212) 949-8859

www.cpradr.org Alternatives@cpradr.org

- 2002, CPR Institute for Dispute Resolution. For permission to reprint bylined articles, please contact both CPR and the author. 


\section{Getting a Head Start: Intake Questions and Mediator Tips}

(continued from page 184)

learn whether counsel or clients have stormed out of depositions, whether there have been accusations of "missing documents," whether one side suspects the other has a client control problem, who's paranoid, and what buttons are being pushed. This will help the mediator determine who should and shouldn't be in a room together, how tightly the me- diator will moderate the dialogue, and how quickly to intervene when the heat rises.

If the mediator uncovers a problematic dynamic between counsel, he or she might come up with a diplomatic way to suggest that another attorney from the firm or the corporation come to the mediation. Or, the mediator might suggest to plaintiff's counsel that the plaintiff be accompanied by a friend or clergyman. The mediator may learn that an "appearance" by the CEO or the immediate past boss would be therapeutic - or disastrous.

A mediator can safely operate with the hypothesis that there is something or someone dysfunctional at work in a mediated dispute. Otherwise, they would have been able to settle it without mediation. Sometimes, the

\section{THE NEUTRAL'S INITIAL CONTACT: CHECKLIST OF MEDIATION ISSUES AND QUESTIONS}

\section{QUESTIONS FOR AN INITIAL CONTACT BY ONE ATTORNEY}

Does the other attorney(s) know you are calling me?

If not, strongly discourage counsel from going into detail about the case. Invoke neutrality.

Are you still in the process of selecting a mediator, or have you agreed?

Experience indicates that a "sell" job is less likely to get you the case than a focus on the issues, dynamics, barriers to settlement, etc.

Have you and your client been involved in mediation before? How did it work? Does it raise any concerns for you about mediation in this case?

It is helpful to know the experience level and expectations or people who are going into the mediation.

If the caller has never been involved in mediation before, you should review the major ground rule--confidentiality--and be prepared to describe it briefly, and how the process usually works.

What is the status of this dispute/case? Is it in litigation? Where are you in the discovery process? Have summary judgment motions been filed/ruled upon or are they likely to be? Has a trial date been set? When?

How did the case get to mediation? Was it referred by the court? Suggestion by counsel? Initiated by the client?

Have there been any previous settlement discussions? How did they go? What was offered and demanded?

\section{ESSENTIAL INITIAL CONVERSATION QUESTIONS}

It would be helpful to have some basic information about the case. Can you tell me: Who are the parties? Who are the lawyers? What law firms? Are any insurers involved? Which insurance companies?

The mediator also needs to check for potential conflicts.

Can you describe what the dispute is about-just a bare bones description - that both parties would agree upon. In other words, what happened? What are the issues?

If counsel begins explaining the client's position and view of the case too strongly, I might interject and ask the attorney to describe them in a way that opposing counsel would agree with him.
What is the nub of the dispute here? Is it the applicable law, or is it different views of the facts? Or both?

You might say: "I am concerned that if I learn too much about the case from you now, opposing counsel may become suspicious that I've been 'tainted' by your call," particularly where the other attorney hasn't yet agreed to mediate or to use the neutral getting the call. So the neutral can tell the caller, "I'd like to save the substance for a conference call with both counsel, but in the meantime, I'd like some basic information." Then turn to the questions listed above.

\section{What's your client's perspective on this?}

You get to this question only if you have decided that you are comfortable learning about the caller's side of the case in this initial call. If you reach this stage, you should follow up with a question about what the caller thinks about the other side's perspective or position, if he or she knows.

Please tell me a little bit about the personalities of the people involved and the relationships.

-Do counsel get along? (Has discovery been difficult?)

- Is there anything I need to know about your client: Is he or she experienced, angry, or emotional about the case?

- What should I know about the clients on the other side(s)?

- What are the dynamics between the parties? Is there any past history between them that might be important to know?

Obviously, some of these questions will be more appropriate than others, depending upon what you have already learned.

Who do you think should be present at the mediation? Who were you planning to bring from your client's organization? What was their role in the underlying dispute? What kind of authority will they have? Is there anyone on the other side whom you think must be there for the mediation to be successful? Anyone who would be a disaster?

Is there potential insurance coverage here? Do you know the insurance coverage? Who will be there on behalf of the insurer? Do you know what level of authority they will have?

Clearly set out the next steps, and gain counsel's approval, and take his or her suggestions. 
dysfunction is limited to the negotiation process; often it is not. The mediator is well served by the answers to questions that will help everyone avoid potential minefields created by the human dynamics in the dispute.

Who do you think should be present at the mediation? Who were you planning to bring from your client's organization? What was their role in the underlying dispute? What kind of authority will they have? Is there anyone on the other side who you think must be there for the mediation to be successful? Anyone who would be a disaster?

The answers to these questions can be critically important. Sometimes, counsel will have arranged to bring someone with the appropriate level of "authority," but who was directly involved in the decisions leading to the dispute. Or, the suggested representative might, upon reflection, be abrasive and difficult, or the perceived "enemy" of the other side. There might be other representatives available more familiar with business operations, and able to suggest or implement creative solutions. Counsel generally are receptive to the mediator's-not the other side's-suggestion to rethink their choice of a representative at the mediation.

\section{Is there potential insurance coverage here? Do you know the insurance coverage? Who will be there on behalf of the insurer? Do you know what level of authority they will have?}

It is critical to know the insurance set up. Counsel often fail to focus on it sufficiently. They may have decided the insurer will be on telephone notice. This is generally a bad idea, but it's much worse if you did not know about it. The insurer may be planning to come, but counsel may not have provided the insurance representative with critical information when a settlement limit has been set. It may be helpful to have an excess carrier attend.

Managing the insurer sometimes is extremely difficult and frustrating. Mediators should ask sufficient questions about the insurance coverage picture and then figure out how that might help or hinder settlement, and what, if anything can be done about it.

Have there been any previous settlement discussions? How did they go? What was offered and demanded?

It may be best to raise the topic of settlement discussions after you have a feel for the case and for counsel-later in the call.
Why wait? If the lawyer responds, "They asked for \$1 million and we offered $\$ 50,000$," he doesn't want you to calculate the midpoint, and forget everything else, which is what lawyers think all mediators do-and exactly what they should not do! The attorney wants the mediator focused on his or her client's problem, on the "just" result, on the merits, and on the unfairness.

Asking first about previous settlement offers is too cold and in a way, too intrusive, before you've gotten to know the party, counsel, and the case.

Don't skip these questions. The mediator wants to know the negotiation history, including any past settlement offers or demands. That history provides a great deal about what the parties are thinking and their bargaining styles. But no matter how far apart the numbers, don't despair. That is why they sought a mediator. You would be amazed how cases with relatively small initial gaps can resist settlement and cases with enormous gaps can fall into place.

If possible, ask about negotiation history in separate conversations. It is amazingly common for counsel have different memories of the last numbers offered. Sometimes this can work to the mediator's advantage, where one lawyer thinks he offered more than the other lawyer remembers. Or, it can create a lot of trouble, when one lawyer thinks the other has already offered more than the first number he puts out in the mediation.

You need to know if there are any discrepancies. If you uncover one that will be problematic in the mediation, you should call counsel back, explain that there is a discrepancy in the way they remember things, and ask permission to tell each side what the other thinks the offers were and demands exchanged to date.

$$
\text { - } \bullet
$$

When the questions are done, the mediator must consider the next steps in the process. Even in a call that has studiously avoided discussion of a legal dispute's particulars, the mediator who has received responses to the above questions will have obtained information invaluable for recommending process steps.

If the attorneys enjoy a reasonably respectful relationship, and a conference call can be arranged in short order, the mediator might suggest a call to settle upon lo- gistics, documents to be exchanged or submitted, and to understand the issues in dispute. The goal of the conference call will be to get the process and logistical details set, as needed for the mediation agreement. If it appears that the dynamics are difficult and the issues are complex, the mediator might suggest at the outset that the conference call will be followed by separate, more substantive conversations with both sides.

If time is short, as mediation must be scheduled prior to a trial or hearing date, and a conference call will be difficult to arrange due to counsel's trial or travel schedules, the mediator might simply arrange to call opposing counsel separately and preliminarily on process issues and logistics. The mediator will send out a mediation agreement based upon the two initial conversations, and if necessary, follow up with more substantive separate conversations with counsel and perhaps with the parties, prior to the mediation session.

As the mediator recommends next steps, he or she can and should be quite transparent about the reasoning, explaining why these steps are more likely to result in successful mediation process.

\section{THE BOTTOM LINE}

The initial contact offers the mediator the opportunity to:

- Demonstrate and communicate neutrality.

- Demonstrate focus on this particular case, the counsel and the parties.

- Demonstrate process agility, flexibility and confidence.

- Express appreciation and understanding of issues in the case and the caller's perspective, but only to the extent expressed, and without signaling agreement or concurrence before hearing the other side's perspective.

- Build trust.

- Begin gathering information to diagnose barriers, spot trouble, and build a final session in the way most likely to achieve constructive settlement.

- Set up the next steps. - Marjorie Aaron 